\title{
Expert System for Tomato Plant Pest Diagnosis Using the Certainty Factor Method
}

\author{
Annafi 'Franz \\ Software Engineering \\ Technology, \\ Agriculture Polytechnic of \\ Samarinda, Samarinda, 75242, \\ Indonesia \\ annafifranz@gmail.com
}

\author{
Sulpiana \\ Software Engineering \\ Technology, \\ Agriculture Polytechnic of \\ Samarinda, Samarinda, 75242, \\ Indonesia \\ iansulpi@gmail.com
}

\author{
Sri Ngapiyatun \\ Gardening Technology \\ Technology, \\ Agriculture Polytechnic of \\ Samarinda, Samarinda, 75242, \\ Indonesia \\ Ngapiyatun.77@gmail.com
}

\begin{abstract}
This research is motivated by the failure of tomato harvest one of which is a pest attack for that program will be carried out to identify pest attacks so that crop failure can be avoided. This expert system will be implemented with the certainty factor method can provide accurate results obtained from calculations based on the weight of the symptoms chosen by the user, able to provide answers to problems that are not certain of truth such as problems diagnosing disease risk, and with this method, the expert illustrates the confidence of an expert with giving the weight of confidence in accordance with relevant expert knowledge. so that researchers increasingly believe that this expert system will be easily accessible and used by the community. From the explanation above for that, the writer makes a system, namely expert system for diagnosing oil palm plant diseases using the certainty factor method which is intended to assist the work of farmers in providing information and conclusions from pests suffered on oil palm plants.
\end{abstract}

Keywords - Expert system, Tomato Plant, certainty

\section{INTRODUCTION}

Today's computer technology continues to support human life so that the computer is no stranger to most people and even has become a daily necessity that is difficult to leave. Because the development of computer technology is very rapid, thus encouraging the many technologies that are able to adopt the processes and ways of thinking of humans that are often called Artificial Intelligence or artificial intelligence, one part of artificial intelligence is an expert system. Expert system contains the knowledge and experience of one or many experts that are transformed into a certain area of knowledge so that it can help many people in solving various kinds of problems that are specific in this case is the problem of diseases in tomato plants (Rismunandar, 1995).

The problem of crop damage due to pests has been a part of agricultural cultivation since humans started farming thousands of years ago. At first humans killed pests simply by physical and mechanical means as a form of natural human defense reaction (Untung, 1993). What is meant by pests are all animals that disturb and harm plants that are cultivated by humans. If the origin is not from animals, the disorder is called a disease, for example interference from viruses, bacteria, fungi, lowrise or slightly higher plants, lack of food elements and others

Tomatoes are fruits that contain lots of vitamins A and $\mathrm{C}$. The vitamin A content reaches $1600 \mathrm{IU}$ which can prevent eye disease. While the vitamin $\mathrm{C}$ content in tomatoes can reach $35 \mathrm{mg}$. In medium sized tomatoes, there are at least 30 calories in them. Very good for maintaining gum health and accelerating wound healing. Tomatoes are the most suitable fruit or vegetables to be served in the form of fresh vegetables. Lack of knowledge of farmers in knowing the types of diseases that attack (Fitriani, 2012).

The diagnostic process requires an expert and experienced expert to produce the right diagnosis. However, the limited time owned by an expert sometimes becomes an obstacle for farmers who will conduct consultations to solve a problem to get the best solution. In this case the expert system is presented as a second alternative in solving problems after an expert. Based on the explanation described, an expert system is needed to diagnose tomato plant pests in the hope of modeling a tomato pest expert system that can provide information about symptoms, pests, and how to control them.

Expert system is an artificial intelligence that learns how an expert thinks and reason in solving a problem and making a decision or drawing conclusions from a number of facts. The basis of an expert system is how to transfer the knowledge possessed by an expert into a computer that provides services to conduct consultations and obtain solutions to a problem resembling an expert

Based on the application of the above background, an expert system was designed with the title "Expert System of Tomato Pest Diagnosis Web-Based Using the Certainty Factor Method".

The purpose of this research is to design and build an expert system application in diagnosing tomato plant pests using the certainty factor method. 
With this application it is expected to help the community, farmers or extension workers in getting tomato plant pest information based on the symptoms that are seen.

\section{LITERATURE REVIEW}

\section{A. Study of literature}

Some of the literature used as guidelines and references in this thesis include:

1. In research conducted by Nurdiawan and Fatimah. (2016) Entitled Development of Expert Systems Diagnosis of Tomato Plant Diseases Based on Visual Prolog. Tomato plant experts in Garut Regency are relatively few, therefore it is necessary to create a system that can provide information, make decisions, and provide solutions regarding tomato plant diseases, to help the counseling process. Expert system diagnosis of tomato plant diseases based on Visual Prolog can diagnose tomato plant diseases based on symptoms experienced by tomato plants that have been developed, testing the functioning of the system and expert validation of the knowledge available in the system. The test results concluded that the expert system of tomato plant disease diagnosis was as expected.

2. Research conducted by Pratama and Ilyas. (2016) entitled the expert system for diagnosing pests and diseases of tomato plants using the heuristic search method. Farmers have a very big role to meet food needs. One of the plants that farmers often plant is tomatoes. Improve the quality and yield of tomato plants, not a few of the farmers who make mistakes when overcoming these problems. Problems faced by farmers are poured into the form of an expert system with a heuristic search algorithm that is able to diagnose diseases and plants in tomatoes. the results of the diagnosis will provide a solution used to resolve the problem.

3. Research conducted by Supina et al., (2018) entitled The Application of Certainty Factor Methods in Expert Systems in Diagnosing Internal Diseases. The inference model used in making this expert system is a certainty factor while the search technique uses Cash Based Reasoning. Determination of the diagnosis in the expert system is done through a consultation process between the system and the user. The determination of the diagnosis in this expert system is done through a consultation process between the system and the user. If the answers entered are in accordance with applicable regulations, the system will provide diagnostic results in the form of disease information. The cause, treatment, and prevention of a disease. This system is called the Expert System (Expert System).
4. Research conducted by Dwilestari and Nurmiati. (2018) Entitled The Expert Style Determination System in Bonsai Plants Using the Certainty Factor Method. In designing and building this expert system application "SPBONSAI" uses UML (Unified Modeling Language) system design. PHP (hypertext preprocessor) programming language, and database storage using SQL (Structured Query Language), this application uses the Twitter bootstrap framework so that the application look more fresh and attractive. This expert system application is designed to determine the style of bonsai which gives the results in the form of images and styles.

\section{B. Expert system}

Expert systems are branches of Artificial Intelligence (AI) which are quite old because this system was developed in the mid-1960s. The Expert System that first appeared was the General-Purpose Problem Solver (GPS) developed by Newel and Simon. Until now, many Expert Systems have been made, such as MYCIN for disease diagnosis, DENDRAL to identify unknown molecular structure mixtures, XCON \& XSEL to help configuration of large computer systems, SOPHIE for electronic circuit analysis, Prospector used in the field of geology to help find and find a deposit, FOLIO is used to help provide a decision for a manager in stock and investment, DELTA is used for maintenance of diesel electric locomotives, and so on.

The term Expert System is derived from the term knowledge-based expert system. This term arises because to solve a problem, Expert System uses the knowledge of an expert that is entered into a computer. Someone who is not an expert uses the Expert System for knowledge assistants. Expert System is a system that uses human knowledge where the knowledge is entered into a computer and then used to solve problems that usually require expertise or human expertise (Turban in Sutojo et al, 2010).

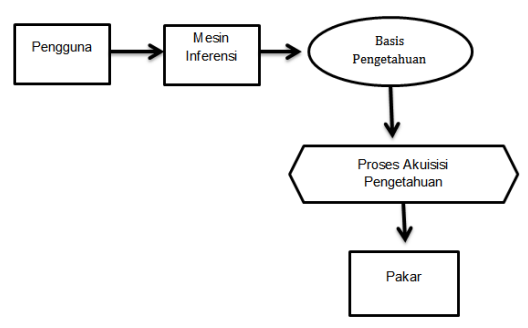

Picture 1. System Structure Diagram

\section{Method certainty Factor}

The method used is the CF (Certainty Factor) method, Certainty Factor is a method that proves whether a fact is certain or uncertain in the metric form commonly used in expert systems, this method is very suitable for expert systems that diagnose something uncertain. Certainty Factors method rules: 
a. McAllister describing the rules for adding two positive Certainty factors are:

b. The rules for adding two negative Certainty are:

c. The rules for adding positive certainty factors and certainly negative factors are more complex: these rules provide an interval scale for certainty factors.

1) Examples for positive facts:
a) Strong suggestive $(\mathrm{CFa}): 0.8$
b) Suggestive $(\mathrm{CFb})$ : 0.6
c) CFcombine $(\mathrm{CFa} \mathrm{CFb})=0.8+0.6(1-$ $0.8)=0.92$

2) Examples for negative facts:
a) Strong suggestive $(\mathrm{CFc}):-0.8$
b) Suggestive ( $\mathrm{CFd}):-0.6$
c) $C F$ combine $(\mathrm{CFc} \mathrm{CFd})=-0.8+-0.6+-0.8$ $*-0.6=-0.92$

3) Examples for positive and negative facts:
a) Certainty factor is $0.88(\mathrm{CFe})$
b) Certainty factor against is $0.90(\mathrm{CFf})$

Certainty factors method this can only process 2 weights in one calculation. For weights more than 2, to do the calculation there is no problem if the weight is calculated randomly, meaning that there are no rules for combining the weights, because for any combination like the results will remain the same. To find out whether a patient has heart disease or not, it is seen from the results of weight calculation after all complaints have been entered and all weights are calculated using the certainty factors method. Patients who are convicted of heart disease are patients who have weights close to +1 with complaints that they have point to heart disease. Whereas patients who have weights close to -1 are patients who are deemed not to have heart disease,

$\mathrm{CF}(\mathrm{H}, \mathrm{E})=\mathrm{MB}(\mathrm{H}, \mathrm{E})-\mathrm{MD}(\mathrm{H}, \mathrm{E})$

$\mathrm{CF}(\mathrm{H}, \mathrm{E})$ : certainty factor of hypothesis $\mathrm{H}$ which is influenced by symptoms (evidence) E. The magnitude of $\mathrm{CF}$ ranges from -1 to 1. Value-1 indicates absolute mistrust while value 1 indicates absolute trust.

MB (H, E): measure of increased belief (measure of increased belief) of hypothesis $\mathrm{H}$ which is influenced by symptoms of $\mathrm{E}$.

$\mathrm{MD}(\mathrm{H}, \mathrm{E})$ : measure of increase of distrust (measure of increased disbelief) of hypothesis $\mathrm{H}$ which is influenced by symptoms $\mathrm{E}$ The basic form of the certainty factor formula of a rule IF E THEN $\mathrm{H}$ is as shown by equation 2 below:

If all the evidence on the antecedent is known with certainty then the equation will be:

$\mathrm{CF}(\mathrm{H}, \mathrm{e})=\mathrm{CF}(\mathrm{H}, \mathrm{E})$

In its application, it is a certainty value given by experts to a rule, while it is a value of trust given by users to the symptoms they experience. For example, the following is a rule with Certainty
Factor
(CF)
given
by
an

expert:CF $(H, E) C F(E, e)$

4) Advantages of the Certainty Factor (CF) Method a) This method is suitable for use in expert systems to measure whether something is certain or uncertain in diagnosing a disease as an example.

b) Calculations using this method in a single calculation can only process two data so that the accuracy of the data can be maintained.

5) Disadvantages of the Certainty Factor (CF) Method

a) The general idea of modeling human uncertainty using numerical certainty factor methods is usually debated. Some people will dispute the notion that the formula for the certainty factor method above has little truth.

This method can only process uncertainty / certainty in only 2 data. Need to do several times the processing of data for data that is more than 2 pieces.

\section{Hypertext Preprocessor (PHP)}

According to Kustiyaningsih (2011), "PHP (or officially PHP: Hypertext Preprocessor) is a server-side script added to HTML". In principle, the server will work if there is a request from the client. In this case the client uses Hypertext Preprocessor (PHP) codes to send requests to the server. The working system of Hypertext Preprocessor (PHP) starts with a request originating from a web page by the browser.

\section{E. Data Flow Diagrams (DFD)}

Data Flow Diagram (DFD) is a diagram that uses notations to logically flow system data. DFD describes the components of a system.

\section{F. Flowchart (Flow Chart)}

Flow charts a system representation chart that describes the physical relations between entities (Subhan, 2012). Flowcharts can be used to present manual activities, computer processing activities or both.

\section{G. Entity Relationship Diagram (ERD)}

Entity Relationship Diagram (ERD) is a set of ways or equipment to describe data or objects created based on and derived from the real world called entities (entities) and relationships (relationships) between these entities by using several notations. (Doro \& Stevalin).

ERD (Entity Relationship Diagram) is a technical approach model that states or illustrates the relationship of a model. In this relationship stated the main thing about ERD is to show data objects (Entity) and relationships (Relationship), which is in the next Entity.

\section{H. Tomato Plant}

Tomato (Lycopersicum Esculentum) is a horticultural product that has the potential, is healthy and has a promising market prospect

Tomatoes are vegetable plants that have been cultivated since hundreds of years ago, but it is not yet known exactly when the initial spread. When viewed from its history, tomato plants originated from America, namely the Andean region which is part of the countries 
of Bolivia, Chile, Colombia, Ecuador, and Peru. Originally in their home country, tomato plants are only known as weed plants. However, over time, tomatoes began to be planted, both in the field and in the yard of the house, as cultivated plants or plants that are consumed (Purwati and Khairunisa, 2007).

A tomato, including plants a year (annual), which means its age, is only for one harvest period. These plants are shrubs or bushes with a length of up to 2 meters. Taxonomically, tomato plants are classified as follows:

Kingdom : Plantae

Subkingdom: Trachebionta

Divisio: Magnoliophyta

Class: Magnoliopsida

Subclass: Asteridae

Order: Solanales

Family: Solanaceae

Genus: Solanum

Species: Solanum Lycopersicum

Binomial name: lycopersicon esculentum L.

The shape, color, taste, and texture of tomatoes are very diverse. There are round, flat, curly, or like a light bulb. The color of ripe fruit varies from yellow, orange, to red, depending on the type of dominant pigment. The taste also varies, from sour to sweet. The fruit is arranged in bunches. The whole fruit is fleshy and contains a lot of water.

\section{RESEARCH METHODS}

\section{A. Place and time of research}

This research will be conducted at the Samarinda State Polytechnic of Agriculture Plantation Study Program. When the research was conducted in the even semester of 2018-2019 the teaching was carried out over a period of approximately 6 (six) months, calculated from October 2018 - March 2019 which consisted of preparation for collecting data information.

\section{B. Tools and Materials}

The tools and materials that will be used in the Guidance and Counseling Expert System research on Student Behavior are as follows:

1. Tool

a. Hardware

1) Laptop (2GB RAM 64-bit type).

2) A printer

3) Internet access

b. Software

1) Xampp Version 3.2.2

2) Sublime Text

3) Google Chrome / Mozilla Fire Fox browser

4) Bootsrap / CSS

5) PhpMyAdmin

2. Material

a. Data on student behavior and symptoms.

b. Symptoms data, pests and weight values of tomato plants. The data can be seen in Table 5, Table 6 and Table 7.

c.
Table 1. Pest Data

\begin{tabular}{|c|c|c|c|}
\hline $\begin{array}{l}\text { Pest } \\
\text { Code }\end{array}$ & $\begin{array}{l}\text { Hama } \\
\text { Name }\end{array}$ & Information & The solution \\
\hline H001 & $\begin{array}{c}\text { FRUIT } \\
\text { CUP }\end{array}$ & $\begin{array}{c}\text { These tomato } \\
\text { caterpillars attack } \\
\text { the leaves, flowers, } \\
\text { and fruit of tomato } \\
\text { plants and their } \\
\text { heads are covered } \\
\text { with fine hairs }\end{array}$ & $\begin{array}{l}\text { install devices that } \\
\text { have ultraviolet } \\
\text { light, kill eggs and } \\
\text { caterpillars, and } \\
\text { clean up wild plants } \\
\text { around tomato } \\
\text { plants. }\end{array}$ \\
\hline $\mathrm{H} 002$ & $\begin{array}{r}\text { SOIL } \\
\text { Worm }\end{array}$ & $\begin{array}{c}\text { Brownish } \\
\text { earthworm and } \\
\text { bigger than a } \\
\text { caterpillar. } \\
\text { Caterpillars are } \\
\text { active at night, and } \\
\text { during the day will } \\
\text { hide in the soil and } \\
\text { under the grass. }\end{array}$ & $\begin{array}{l}\text { clean weeds, so } \\
\text { there is no hiding } \\
\text { place for these } \\
\text { caterpillars. } \\
\text { Chemically it can be } \\
\text { sprayed with } \\
\text { curacron, regent or } \\
\text { prevaton } \\
\text { insecticides and } \\
\text { spraying should be } \\
\text { done when the } \\
\text { caterpillar is active, } \\
\text { ie at night. }\end{array}$ \\
\hline $\mathrm{H} 003$ & $\begin{array}{l}\text { GREEN } \\
\text { LEAVES }\end{array}$ & $\begin{array}{l}\text { These green lice } \\
\text { become a vector } \\
\text { (distributor) of the } \\
\text { virus so that } \\
\text { tomatoes can be } \\
\text { attacked by viral } \\
\text { diseases }\end{array}$ & $\begin{array}{l}\text { The use of paper } \\
\text { mulch can repel } \\
\text { fleas because it } \\
\text { reflects sunlight and } \\
\text { wild plants or weeds } \\
\text { around the area of } \\
\text { tomato plants must } \\
\text { be sited because } \\
\text { they can be a } \\
\text { sanctuary for fleas. }\end{array}$ \\
\hline H004 & $\begin{array}{c}\text { WHITE } \\
\text { FLY }\end{array}$ & $\begin{array}{l}\text { These lice when } \\
\text { disturbed will } \\
\text { scatter like fog or } \\
\text { white clouds }\end{array}$ & $\begin{array}{c}\text { Weed around } \\
\text { tomato plants must } \\
\text { be cleaned so that it } \\
\text { does not become a } \\
\text { host of white flies } \\
\text { and Sprayed with } \\
\text { diazinon, malathion, } \\
\text { azinpos-methyl and } \\
\text { others. }\end{array}$ \\
\hline H005 & $\begin{array}{c}\text { FLY } \\
\text { FRUIT }\end{array}$ & $\begin{array}{l}\text { The flies attack } \\
\text { tomato plants by } \\
\text { injecting fruit and } \\
\text { leaving eggs in the } \\
\text { skin of the fruit }\end{array}$ & $\begin{array}{l}\text { environmental } \\
\text { sanitation, dispose } \\
\text { of and destroy the } \\
\text { fruit attacked by } \\
\text { these pests, and do } \\
\text { the processing of the } \\
\text { soil around the plant } \\
\text { so that pupae in the } \\
\text { soil die. }\end{array}$ \\
\hline
\end{tabular}

Table 2. Data Symptoms

\begin{tabular}{|l|l|}
\hline $\begin{array}{c}\text { Symptom } \\
\text { Code }\end{array}$ & \multicolumn{1}{c|}{ The symptoms } \\
\hline G001 & The leaves become curly and stunted \\
\hline G002 & Attacking the leaves \\
\hline G003 & The base of the bitten stem will break easily and die \\
\hline G004 & Attack on flowers \\
\hline G005 & There is a hole in the fruit \\
\hline G006 & Broken fruit and many holes \\
\hline G007 & Plants that are still easy but withered \\
\hline G008 & The leaves curl down \\
\hline G009 & Leaves are easily brittle \\
\hline G010 & The leaves narrow like a ribbon \\
\hline G011 & Leaves change color to mosaic \\
\hline G012 & Cut the plant at the base of the stem or leaf stalk \\
\hline G013 & Leaves are easily brittle \\
\hline G014 & Make a hole in the fruit \\
\hline G015 & Leaves become smaller \\
\hline G016 & Leaves curled upwards \\
\hline G017 & The fruit decays due to fungus or bacteria \\
\hline
\end{tabular}




\begin{tabular}{|c|l|}
\hline $\begin{array}{c}\text { Symptom } \\
\text { Code }\end{array}$ & \multicolumn{1}{c|}{ The symptoms } \\
\hline G018 & Leaves like veiled white flour \\
\hline G019 & Fruit covered with white flour \\
\hline G020 & If the fruit is opened there is a white maggot \\
\hline
\end{tabular}

Table 3. Weight Data

\begin{tabular}{|c|c|c|}
\hline Pest Code & Symptom Code & Symptom Weight \\
\hline H001 & G002 & 0.2 \\
\hline & G004 & 0.5 \\
\hline & G005 & 0.7 \\
\hline & G006 & 0.9 \\
\hline H002 & G003 & 0.5 \\
\hline & G007 & 0.4 \\
\hline & G009 & 0.3 \\
\hline H003 & G012 & 0.9 \\
\hline & G001 & 0.2 \\
\hline & G008 & 0.4 \\
\hline & G010 & 0.6 \\
\hline & G011 & 0.7 \\
\hline H004 & G013 & 0.3 \\
\hline & G015 & 0.2 \\
\hline & G016 & 0.6 \\
\hline & G018 & 0.7 \\
\hline H005 & G019 & 0.9 \\
\hline & G017 & 0.5 \\
\hline
\end{tabular}

To manage knowledge in the system carried out by tomato plant experts as the expert system admin. The value of the user's answer to the question will be carried out the value conversion process. Table 3 represents the certainty Factor (CF) value of the evidence from the answers to the diagnostic questions.

Table 4. Certainty Factor (CF) evidence.

\begin{tabular}{|c|c|c|}
\hline$\#$ & UNCERTAIN TERM & $\begin{array}{c}\text { VALUE OF CF } \\
\text { EVIDENCE }\end{array}$ \\
\hline 1 & Very confident & 0.4 \\
\hline 2 & Sure & 0.3 \\
\hline 3 & Not sure & 0.2 \\
\hline
\end{tabular}

Establishment of rules used in the system. For example in the establishment of the first rule, if a caterpillar is damaged and many holes in the hole AND attack the leaves AND attack the flower AND there is a hole in the fruit. The formation of rules can be seen in Table 9.

Table 5. Rule Formation

\begin{tabular}{|c|c|c|}
\hline Rule & THEN & IF \\
\hline Q1 & H001 & G002 \& G004 \& G005 \& G006 \\
\hline R2 & H002 & G003 \& G007 \& G009 \& G012 \\
\hline R3 & H003 & G001 \& G008 \& G010 \& G011 \& G013 \\
\hline Q4 & H004 & G015 \& G016 \& G018 \& G019 \\
\hline Q5 & H005 & G017 \& G014 \& G020 \\
\hline
\end{tabular}

\section{Research procedure}

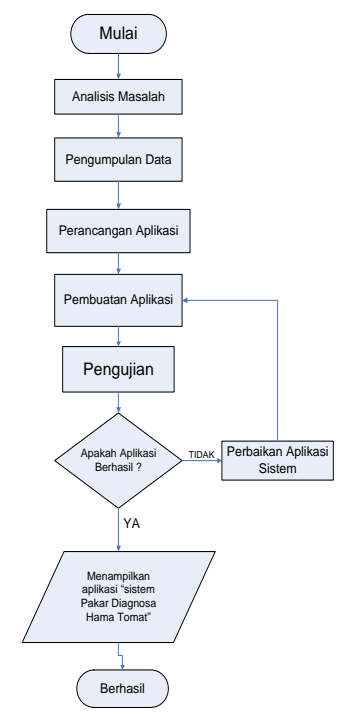

Picture 2. Research Procedure Diagram

\section{Systems Design Analysis}

Context Diagram consists of 2 (two) entities, namely experts (Admin) and users (users). Admin provides input to the system in the form of pest name data, symptoms and information about pests. Users in diagnosing pests give symptoms to the system which is a fact and then the system provides the results of an appropriate consultation can be seen in Figure 3.

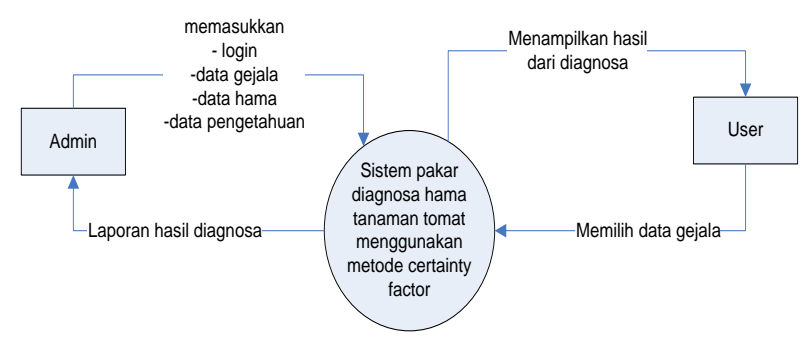

Picture 3. Context Diagram

Data Flow Diagram (DFD) level 1 consists of 4 namely consultation, admin login, input of pest and symptom data, input of knowledge base. The first process is consultation, the user is directed to the consultation page by selecting the appropriate pest and then directed to the consultation process where this process will display the symptoms of adjusting pests that have been selected by the user. the database. Level 1 DFD process can be seen in Picture 4. 


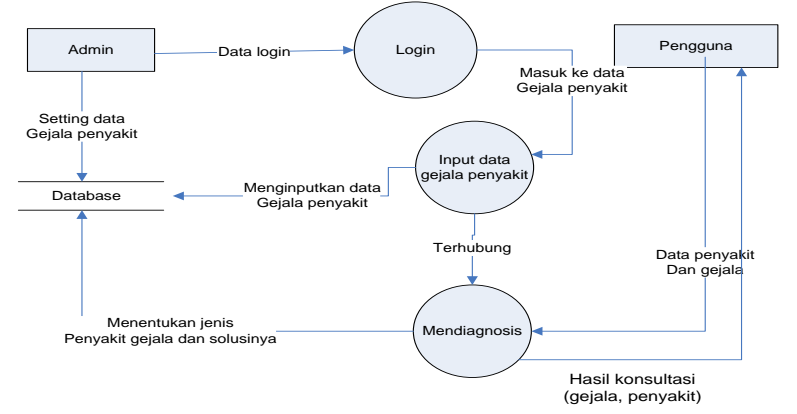

IV. RESULTS AND DISCUSSION

A. Results

1. Display login page.

The login page display is the initial view of the admin page when the admin first enters this expert system application.

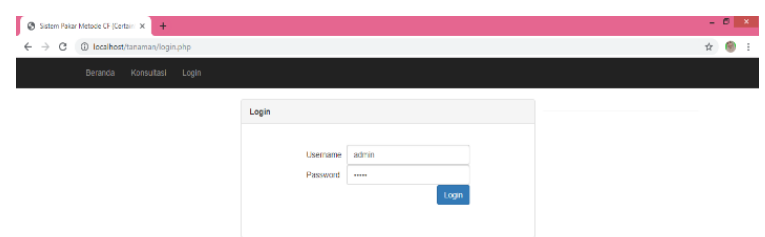

Picture 4. Login page

2. Display Home Page

Initial display of the home page when first entering this expert system application.

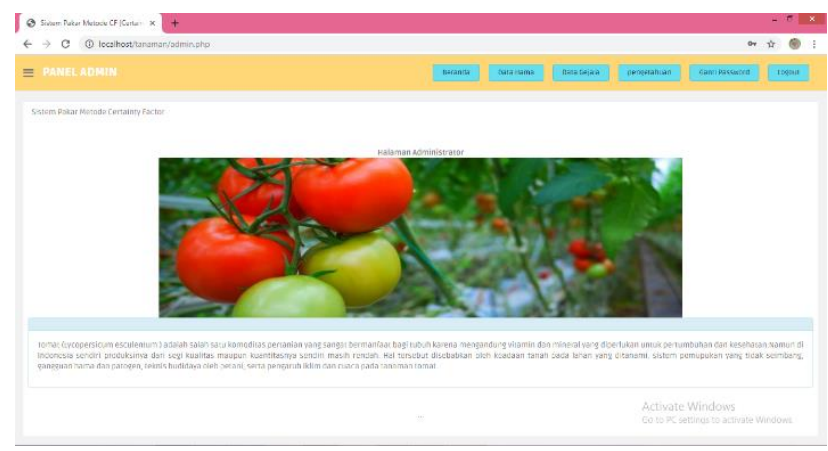

Picture 5. Home Page

\section{Pest Data}

The pest data page display displays menus and results from existing pest data on tomato plants, the tomato data can be edited if there are errors from the tomato data.

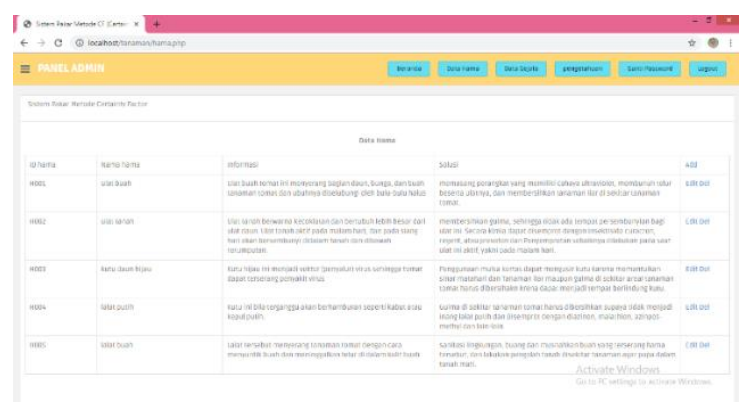

Picture 6. Pest Data

\section{Data Symptoms}

The Symptoms Data page display displays a menu, the symptoms data display of tomato plant pests. Where the data can be edited and deleted.

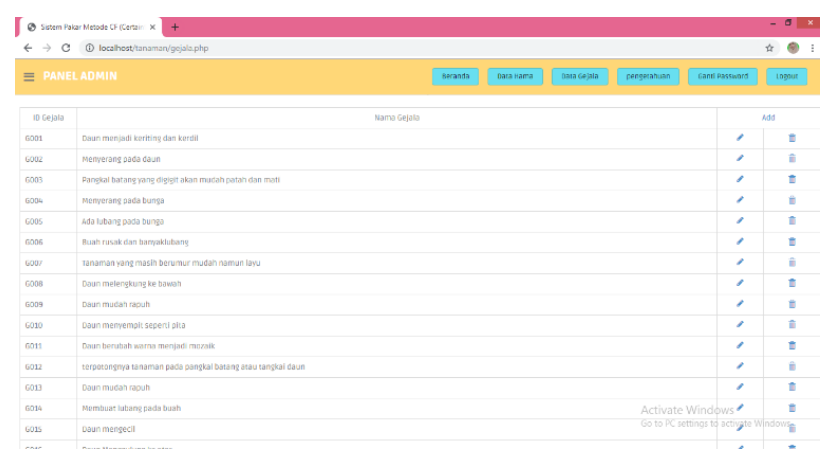

Picture 7.Data Symptoms

\section{Knowledge Data}

The function of choice data is where this data assesses the level of certainty of each pest. If there are errors the data can be edited to be changed
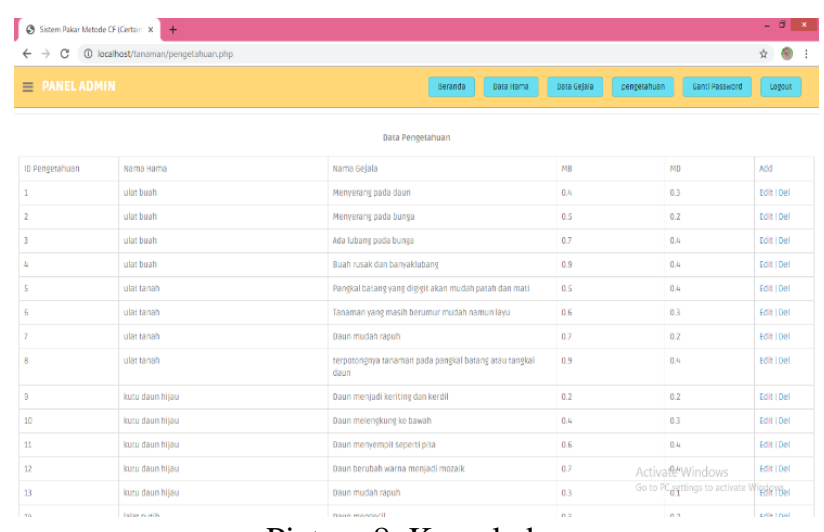

Picture 8. Knowledge

6. Consultation

The consultation page is the page that becomes the main part of the program because on this page the user conducts a consultation so that the user knows what diseases attack the user's tomato plant. 


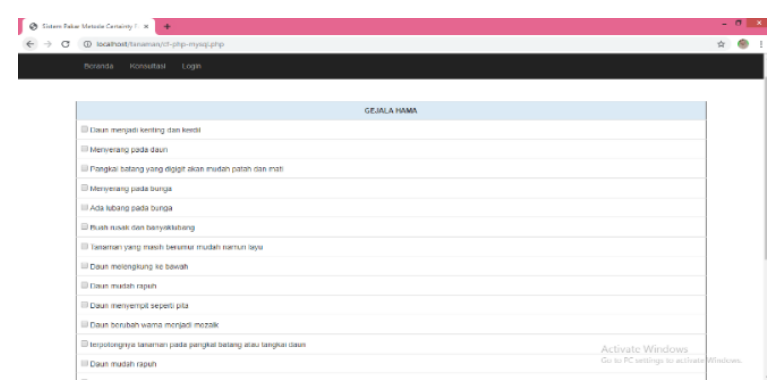

Picture 15. Consultation

7. What pests attack the tomato plants in the consultation yard.
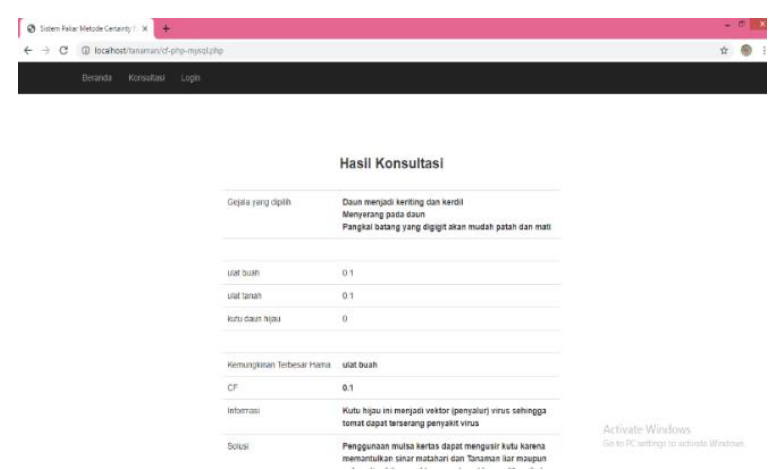

Picture 16. Consultation Results

\section{CONCLUSIONS}

An expert system using certainty web-based method has been successfully developed. This expert system can help farmers provide information and the conclusions of the pests suffered on tomato plants. This new system is used to find out 5 pests of tomato plants. For further research more than 5 pests can be developed on tomato plants. The method can use methods other than certainty factors. The development of the technology can go to Android.

\section{REFERENCES}

Arief, MR 2011. Dynamic web programming using PHP and MySQL. Yogyakarta: Andi Offset

Doro, E. and Stevalin B. 2009.Data Analysis Using ERD and Data Warehouse Conceptual Model. Bandung.

Fitriani, Emi. 2013. The Interests of Tomato Cultivation.Pustaka Baru Press, Yogyakarta

Hermawan N. and Destiani FD 2016. "Development of Expert System for Tomato Plant Disease Diagnosis Based on Visual Prologue". Algorithm Journal, Garut College of Technology. ISSN: 2302-7339 Vol. 13 No. 1

Kartika, E et al. 2015. "Growth and Yield of Tomato (Lycopersicum Esculentum Mill.) Plants in Various Percentage Shade". Agrotechnology Study Program, Faculty of Agriculture, University of Tadulako, Palu. Issn: 2338-3011

Kusuma UW et al 2017. "Expert System to Diagnose Tomato Plant Diseases Using the Forward Chaining
Method".Informatics Engineering, Faculty of Engineering, Nusantara University Pgri Kediri. Vol. 3, No. 2

Purwati, E. and Khairunisa. 2007. Lowland Tomato Cultivation with Superior Varieties and Resistant to Pests and Diseases. Jakarta: Self-help Spreaders. 67 p.

Primary ID and Ilyas M. 2016. "Expert System for Diagnosing Pests and Tomato Plant Diseases Using the Heuristic Search Method". FacultySTMIK AMIKOM Yogyakarta Informatics Engineering. ISSN: 2302-3805

Rismunandar, 1995. Tomato Plants. Sinar Baru Algensindo. Bandung.

Raharjana AJ (2015). Making Sequence Diagram Models With Reverse Engineering Database Applications on Smartphones To Maintain Consistency of Software Design, 133-142.

Sholichin SH 2005. Using Xampp Web Server Program, MySQL Database, and PHP. Samarinda ...

Sutojo et al 2010. Artificial Intelligence. Semarang: Andi Offset. Pages: 160-178. 